\title{
An investigation of challenges in the production and comprehension of speech acts among Iranian EFL learners: a qualitative approach
}

\begin{abstract}
The purpose of this research was to investigate the challenges that Iranian EFL learners encounter in the production and comprehension of speech acts in English in a variety of communicative situations. The participants of the research comprised 30 Iranian EFL learners. For this purpose, semi-structured interviews were utilized as the instrument for the collection of data and the data were analyzed qualitatively through thematic analysis. The results showed that most of the respondents (28 out of 30 ) declared that they have more problems in formal situations to perform speech acts. In addition, the findings of learners interview showed that the problems Iranian EFL learners faced in producing the speech acts include grammar, expression, vocabulary, and structure. One respondent just mentioned that she had problem in the comprehension aspect. The implication of this study is for Iranian language instructors, materials writers and curriculum developers to provide language learners with more input and practice in the language classrooms.
\end{abstract}

